\title{
Performance Correlational Possibility at the Transition between Two Levels: An Education Experience in a Congolese Urban Subdivision
}

\author{
Kahambu Matita ${ }^{1}$, PhD, Leandre Thamuithe ${ }^{2}$, PhD Student \\ *Corresponding Author: Kahambu Matita

\begin{abstract}
In all areas of life, everyday reality has largely proven that during the transition from one level to another, some imbalance arises. School life is no exception to this law of nature. By changing the level of study, the learner is psychologically destabilized. More abundant subjects, alternation of new and experienced teachers, their methods of communication, and finally the change of classmates and of schools can all be disturbing to the learner. The physical and social environments can affect the learner either positively or negatively. In this study, we examined the intensity of adaptation to this level change of study as advocated by Karl PEARSON, through the BRAVAIS PEARSON and SPEARMAN formula of correlation coefficient for scientifically consistent conclusions. The study was conducted on 6th-year pupils of elementary
\end{abstract} \\ school passing to the 1st year of secondary school in Butembo, Democratic Republic of Congo.
}

Keywords: Correlation, Primary Education, Evaluation, and Performance

\section{INTRODUCTION}

Education, which is the work of training and developing the learner's physical, intellectual, and moral abilities, is the basis of important government political decisions through the world. It is a socialization process of individuals; "a regulated, structured and controlled whole" (Dreano, 2015, p. 15). Education is a system, highly organized and formal (Duru-Bellat \& Mingat, 1997), located in schools. In order to prove their abilities, the subjects are led to undergo a school performance assessment based on a student-teacher effect and affecting the final results of the school year. In addition, school is systematically organized into levels: primary, secondary and tertiary. In order to move from one level to another, every government sets clear guidelines and requirements "to assess well the performances of future executives before availing them to society" (Planchard, 1998, p. 5).

Although it has a different vision and level, the Congolese government endorses this truth about schooling: primary education allows the learners to cope with secondary education where performance is better assessed. Understandably, the results attained in the first year of the secondary level reflect the correlation of the training acquired in the six years of the primary education, which is supported by the Primary Education National Test (PENT) ["Test National de Fin d'Etudes Primaires" (TENAFEP)]. During the period under review, primary school students massively passed the test during years 2014 to 2016 with an encouraging average of $97 \%$.

The main question is, were these outstanding results reflected at the secondary level? Was this correlation possibility identical for gender and school networks in Butembo? In response, the correlation possibility at the two levels may have taken place, but at slightly divergent degrees with variance that does not exceed 50\%. The correlation divergences would not be identical according to gender or school networks throughout the education area for several causes. Variances would therefore be shared.

Through this study, we intended to encourage the decision-makers of the Congolese and world education systems to audit their assessments in case of very significant achievements, to revisit the system in case of correlation absence, to recreate a harmonious and sincere collaboration between education system levels, to identify education system and assessment deficiencies in order to pinpoint interesting ongoing research fields. 
Being analytical, this research aimed to redirect the teaching and assessment system for a strong correlation between the education levels. Thus, we dwelt on the organization of the primary education final examinations and scrutinized their results in order to help consolidate the education system or redirect it into teaching and evaluation, testing the correlation method in order to ensure that the education system is effective.

We used the correlation method more in its qualitative aspect than in its quantitative one. This method is recommended by Spearman, through intensity and sense criteria and forms of relationship between variables. Being more interested by intensity, we analyzed whether the connection is positive or negative, linear, monotonous, or neither linear nor monotonous. Upstream and downstream, we used the documentary technique, then the statistical calculations by the Bravais Pearson testing. We studied the school performance correlation degree of first year secondary students in the 2015-2016 year in Butembo City. It is from the excellent test performance attained at the end of their 2014-2015 primary level that our scientific curiosity was aroused.

\subsection{Correlation in Education}

Before going into the more detailed content of this discussion, we must agree on the meaning of the key words used in this study. These words are: correlation, correlation coefficient significance, assessment and finally performance.

\subsection{Correlation and Its Coefficient}

The term "correlation" expresses a relationship between two facts or two phenomena which influence one another. In mathematics, correlation is "a connection between two variables" expressed in degrees (Howell, 1998, p. 264) such as X and Y are random. Their degree of relationship is measured in terms of the correlation coefficient (Yadolah, 1993). Their values are located in the interval between -1 and 1; two extreme points representing a negative or positive linear relationship between two variables. The value zero (0) meanings the absence of any linear relationship.

Thus, as method, the correlation allowed us to experiment:

- The positive linear connection whereby two variables $X$ and $Y$ (success in the primary then in the secondary) evolve in the same direction as the performance improvement in the primary level;

- The negative linear connection whereby the two school results evolve in the same decreasing direction such as the decrease in the primary level involves the decrease in the secondary;

- The positive but nonlinear monotonous connection whereby the two variables of the grades evolve in the same direction, but with the gradient which is different according to the level of the primary;

- The nonlinear and non-monotonous connection whereby the two performances influence each other in a functional, non-monotonous relationship. Y may increase or decrease according to the value of $X$;

- Or the absence of connection; that is, the two performances - primary and secondary-have no correlation. Neither of the two influences the other. The other characteristic is that $\mathrm{X}$ (or $\mathrm{Y}$ ) is a constant whatever may be the value of the second variable $\mathrm{Y}$ (or $\mathrm{X}$ ).

\subsection{Assessment}

In pedagogy, assessment is the process of measuring the level of acquisition of the student of a lesson previously learned. Coming from the verb to assess, assessment "examines the adequacy between a set of data and criteria matching with the set objective in view of a decision making", (Deketele, 1986, p. 11); an estimated determination or approximated measure of capacity and quality demonstrated by a learner (Lafon, 1991, p. 176). Assessment in pedagogy is the evaluation of the results of an educative action against the objectives. Assessment is classified into predictive assessment (preparing the future behavior of the learner) and formative assessment (setting an overview at the end of a training) in order to determine and check the result of previous training actions. The current study examined the ability of 2016 first-year secondary students against the performance attained at the 2015 Primary Education National Test in Butembo City. 


\subsection{Yield}

Yield is the outcome, the performance. In education, yield or school performance is the relationship between the learner and action applied on him or her according to the set objective; that is, the knowledge and the level of understanding, and it carries a value to the set norms of the grading system. Last, it is a relationship between the result and the means implemented in order to gain the result of two subjects of the same nature and that these results are assessed in the same unit (Khol, 1967, pp. 126-127). The school performance is positive when the objective is reached or negative when the student fails, meaning that the objective has not been reached.

\subsection{Performance}

Performance produces and helps understand better the expected behavior. School performance is the intellectual ability whereby the student presents logically and consistently a better outcome. The teacher acknowledges it a priori with good grades.

\subsection{Previous Work}

In order to demarcate our study, we consulted another study as rich as relevant carried out in 2005 in France by Philippe Guimard, Cos Nefroy, and Frorin. Being also correlational, theirs dealt with a cognitive assessment of standardized behavior predicting the ability and performance of students in France, on a sample of 5,549 students. They aimed at checking whether there was any correlation between teachers' assessment and students school performance from first year of primary school (preparatory) to the sixth year of secondary school.

The panel consisted in the assessment and prospective management of the ministry of education. The school ability and performance were assessed by the teachers in a standardized protocol to the sixthyear students in French and Mathematics. At the end, the analysis of the data about their school career proved that the assessment of the teachers brings a significant contribution to the explanation of initial school performance and the socio-demographic variables. The explanation of this study in the field of docimology support the internal examination. Our study matches with theirs by the statistical population - the students. The difference is that they ran a predictive cognitive assessment whereas ours was a correlation analysis.

\section{MeThOdOLOGY}

In this study, 13, 452 students in first year of secondary schools from 185 schools made up our sample. In order to gather our sample, two techniques were used: the quota and the reasoned choice (Syalikowiwe, 2015). We applied the second one to schools with reduced numbers in the first year. And the Vincent Giard Law of taking 1/2, 1/4, 2/4, 1/3, 2/3, and 1/5, depending on whether the size of the population is small or big affected each stratum. Thus, $1 / 4$ was sufficed per school.

Table1. Numbers of Students According to Management System and Sample

\begin{tabular}{|l|l|l|l|l|l|l|l|}
\hline & Management system/schools & \multirow{2}{*}{ No of schools } & \multicolumn{2}{|l|}{ No of students } & \multirow{2}{*}{ Total } & \multicolumn{2}{l|}{ Sample } \\
\cline { 4 - 7 } & & & Boys & Girls & & Schools & Students \\
\hline 01 & Public Secular & 16 & 486 & 475 & 961 & 4 & 263 \\
\hline 02 & Public Catholic & 26 & 1904 & 2125 & 4029 & 7 & 418 \\
\hline 03 & Public/A.S.J & 07 & 240 & 285 & 525 & 2 & 102 \\
\hline 04 & Public/CBCA & 15 & 606 & 681 & 1287 & 3 & 177 \\
\hline 05 & Public/CEBCE & 09 & 369 & 376 & 745 & 2 & 134 \\
\hline 06 & Public/CEPAC & 05 & 171 & 199 & 370 & 1 & 31 \\
\hline 07 & Public/CAC & 03 & 142 & 112 & 254 & 1 & 22 \\
\hline 08 & Public/CECA 20 & 02 & 34 & 41 & 75 & 1 & 51 \\
\hline 09 & Public/CEBA & 05 & 185 & 251 & 436 & 1 & - \\
\hline 10 & Public/ECK & 04 & 90 & 127 & 217 & 1 & 60 \\
\hline 11 & Public Islamic & 03 & 81 & 119 & 200 & 1 & 45 \\
\hline 12 & Private ASSONEPA & 90 & 1944 & 2409 & 4353 & 23 & 678 \\
\hline & Total & $\mathbf{1 8 5}$ & $\mathbf{6 2 5 2}$ & $\mathbf{7 2 0 0}$ & $\mathbf{1 3 4 5 2}$ & $\mathbf{4 7}$ & $\mathbf{1 9 8 1}$ \\
\hline
\end{tabular}

Source: 2015-2016 School Start in Butembo School Subdivision.

The selected schools represented $1 / 4$ of the total number of schools per network management in the subdivision. Thus, out of the 185 schools in the subdivision, the sample was 47 schools, representing 
1,981 students who were examined. The analysis and treatment of the data gathered of the final results of students in the sixth year of primary school and of the first year of secondary school was done through the calculation of the Bravais Pearson correlation coefficient, expressed in the following formula:

$$
\Upsilon_{\mathrm{xy}}=\frac{n \Sigma x y-(\Sigma y)(\Sigma y)}{\left[n\left(\Sigma x^{2}\right)-(\Sigma x)^{2}\right]\left(n(\Sigma y)^{2}\right.}
$$

With Yry representing the correlation coefficient of Bravais Pearson, $n=$ size of the sample, $x=1 ; y=2$. The correlation coefficient referred to the table of the Bravais Pearson critical numerical values, in relationship with the degree of latitude. The correlative value was transformed into value $t$ of students when applying the following conformity coefficient formula: $t^{t_{0}=} \cdot \sqrt{\frac{\sqrt{1-2}}{1-r^{2}}}$ to=observed value of $t$ student, $\Upsilon=$ correlation coefficient, $n=$ sample. For the test that was significant, the determination coefficient was represented by $\Upsilon=$ correlation coefficient (Mukulu, 2006). $\mathrm{CD}=\mathbf{r}_{\mathbf{n}}^{\mathbf{2}} \times 100$

\section{School Performance of Students at THE Two LeVEls}

\subsection{General Presentation of School Performance in School Years 2015 and 2016}

The data is presented in tables by numerical values corresponding to gender, network management according to the coefficients of: correlation, conformity and determination.

Table2. Correlation of School Results in Primary ( $6^{\text {th }}$ year) and Secondary ( $1^{\text {st }}$ year $)$ Levels

\begin{tabular}{|c|c|c|c|c|c|c|}
\hline $\begin{array}{c}\text { Correlation } \\
\text { coefficient }\end{array}$ & OV & CV & $\boldsymbol{n}$ & $\begin{array}{c}\text { Statistical } \\
\text { conclusion }\end{array}$ & $\begin{array}{c}\text { Determination } \\
\text { coefficient }\end{array}$ & $\begin{array}{c}\text { Statistical } \\
\text { decision }\end{array}$ \\
\hline $\mathbf{0 . 3 9 6 5 7 6 1 8}$ & $19.21790234 \approx 19.217$ & 1.960 & 1981 & S.T. & $15.72726665 \%$ & H 0, H1 \\
\hline
\end{tabular}

Source: Our investigations

Given this table, the application of the Bravais Pearson reveals a value of 0.3965761 which is in correlation with the conformity coefficient. Thus, we obtain an observed value of 19.217 at the threshold of $95 \%$ and 1979 as number of latitude degree. The table of critical values of $t$ of students gave a value of 1.960, lower than the observed value. Therefore, the low significant positive connection is significant, with a determination coefficient of $15.72 \%$. So, the school results of the students in the first secondary year were influenced by those of the primary level in $15.72 \%$ with the rest of $84.28 \%$ to be explained by other school factors.

\subsection{School Performance of Students by Gender}

Table3. Correlation of the Results at Two Levels for Girls and Boys

\begin{tabular}{|c|c|c|c|c|c|c|c|}
\hline G & $\begin{array}{l}\text { Correlation } \\
\text { coefficient }\end{array}$ & OV & CV & $n$ & $\begin{array}{l}\text { Statistical } \\
\text { conclusion }\end{array}$ & $\begin{array}{l}\text { Determination } \\
\text { coefficient }\end{array}$ & \begin{tabular}{|l} 
Statistical \\
decision
\end{tabular} \\
\hline Girls & 0.383296329 & & 1.960 & 1087 & S.T. & 14.69160758 & $\mathrm{H} O, \mathrm{H} 1 \mathrm{~V}$ \\
\hline Boys & 0.409791286 & $13.34187269 \approx 13.341$ & 1.960 & 884 & S.T. & $16.79288981 \% \approx 16.79 \%$ & $\mathrm{HO}, \mathrm{H} 1$ \\
\hline
\end{tabular}

The correlation values of 0.383296329 for girls and of 0.409791286 for boys gave respectively the conformity coefficients of observed value of 13.738 at the threshold of $95 \%$ with a degree of latitude of 1,095 for girls, and of 13.341 at the threshold of $95 \%$ with a degree of latitude of 882 for boys; the $t$ of student being 1.960 for girls and 1.960 for boys. In fact, the observed values are higher than their critical values. Therefore, there exists a significant positive relationship by gender such as the school performance of sixth year in primary school has greatly influenced the one obtained in the first year of secondary school in 2016 in Butembo City.

\subsection{School Performance of Students by Network Management}

In Congo, schools are managed by three systems: the Public Secular Schools, the Public Religious Schools, and the Private Schools, grouped in the National Association of Private Schools. The table below shows them. 
Performance Correlational Possibility at the Transition between Two Levels: An Education Experience in a Congolese Urban Subdivision

Table4. Performance Correlation of Students by Level and by Network Management

\begin{tabular}{|c|c|c|c|c|c|c|c|}
\hline Management & $\begin{array}{c}\text { Correlation } \\
\text { coefficient }\end{array}$ & $\mathbf{O V}$ & $\mathbf{C V}$ & $n$ & Sc & $\begin{array}{c}\text { Determination } \\
\text { coefficient }\end{array}$ & $\begin{array}{c}\text { Statistical } \\
\text { decision }\end{array}$ \\
\hline \multicolumn{8}{|c|}{ Public Secular Schools } \\
\hline & 0.317507839 & $5.409402135 \approx 5.409$ & 1.960 & 263 & S.T. & $10.08112278 \% \approx 10.08 \%$ & $\mathrm{H}+, \mathrm{H} 1$ \\
\hline \multicolumn{8}{|c|}{$\begin{array}{c}\text { Public Religious Schools } \\
\end{array}$} \\
\hline Catholic & 0.500912003 & $11.80434587 \approx 11.804$ & 1.960 & 418 & S.T. & $25.09128347 \% \approx 25.09 \%$ & $\mathrm{HO}, \mathrm{H} 1$ \\
\hline Adventist & 0.231432435 & $2.378909411 \approx 2.378$ & 1.960 & 102 & S.T. & $5.356097197 \% \approx 5.35 \%$ & $\mathrm{HO}, \mathrm{H} 1$ \\
\hline CBCA & 0.508914479 & $7.820831941 \approx 7.820$ & 1.960 & 177 & S.T. & $25.89939469 \% \approx 25.89 \%$ & $\mathrm{HO}, \mathrm{H} 1$ \\
\hline CEBCE & 0.33829608 & $4.13024652 \approx 4.130$ & 1.960 & 134 & S.T. & $11.44442377 \% \approx 11.44 \%$ & $\mathrm{HO}, \mathrm{H} 1$ \\
\hline $\mathrm{CAC}$ & 0.633555714 & $4.409738725 \approx 4.409$ & 2.045 & 31 & S.T. & $40.13928427 \% \approx 40.13 \%$ & $\mathrm{HO}, \mathrm{H} 1$ \\
\hline CECA 20 & 0.575157076 & $3.14430985 \approx 3.144$ & 2.086 & 22 & S.T. & $33.08056621 \% \approx 33.08 \%$ & $\mathrm{HO}, \mathrm{H} 1$ \\
\hline CEBA & 0.398721524 & $3.043436626 \approx 3.043$ & 2.011 & 51 & S.T. & $15.89788537 \% \approx 15.89 \%$ & $\mathrm{HO}, \mathrm{H} 1$ \\
\hline ECK & 0.636806367 & $6.290043192 \approx 6.290$ & 2.002 & 60 & S.T. & $40.55223491 \% \approx 30.16 \%$ & $\mathrm{HO}, \mathrm{H} 1$ \\
\hline COMICO & 0.549251996 & $4.310006581 \approx 4.310$ & 2.017 & 45 & S.T. & $30.116777551 \% \approx 30.16 \%$ & $\mathrm{HO}, \mathrm{H} 1$ \\
\hline \multicolumn{8}{|c|}{ Private Schools } \\
\hline Assonepa & 0.357508071 & $9.953003352 \approx 9.953$ & 1.960 & 677 & S.T. & $12.78120208 \% \approx 12.781 \%$ & $\mathrm{HO}, \mathrm{H} 1$ \\
\hline
\end{tabular}

The application of the Bravais Pearson test gave the correlation values of 0.317507839 for public secular schools, and of 0.357508071 for private ones. Their observed values are from 1.960 such as shown in OV column up to 9.953 , still at the threshold of $95 \%$ with a latitude degree of 675 and a critical value $\boldsymbol{t}$ student of 1.960 in private schools.

In fact, in the table, most of the observed values are higher than the critical value. The statistical decision is to the reject the null hypotheses in favor of affirmative ones. Therefore, there is a significantly positive connection, directly correlated between the school result of the sixth primary school year and that of the first secondary school year. As a proof of common variance, this correlation is explained by the result of the sixth primary school year at $10.08 \%$ only, the $89.92 \%$ of the rest being still explained by other factors.

\subsection{Correlation of School Results at Two Levels in Schools by Network}

This section answers the question which asked whether the correlation may have been identical in all schools in Butembo, given the exceptional results during in 2015.

Table5. Results Correlation for Primary and Secondary School Students

\begin{tabular}{|c|c|c|c|c|c|c|c|}
\hline $\begin{array}{l}\text { System } \\
\text { Schools }\end{array}$ & $\begin{array}{c}\text { Correlation } \\
\text { coefficient }\end{array}$ & $\mathbf{O V}$ & $\mathbf{C V}$ & $n$ & Sc & $\begin{array}{l}\text { Determination } \\
\text { coefficient }\end{array}$ & $\begin{array}{l}\text { Statistical } \\
\text { decision }\end{array}$ \\
\hline ALEMBA & 0.147937685 & $0.73280699 \approx 0.732$ & 2.064 & 26 & N.S.T & & $\mathrm{HOV}$ \\
\hline KVAGHENDI & 0.414916191 & $3.648177589 \approx 3.648$ & 1.998 & 66 & S.T. & $17.21554456 \approx 17.21 \%$ & $\mathrm{H} \theta, \mathrm{H} 1$ \\
\hline UTEMBO & 0.30021288 & $3.240350947 \approx 3.240$ & 1.984 & 108 & S.T. & $9.012777332 \approx 9.01 \%$ & $\mathrm{H}+, \mathrm{H} 1$ \\
\hline MALIO & 0.478031758 & $3.078703151 \approx 3.078$ & 2.037 & 34 & S.T. & $22.85143617 \approx 22.85 \%$ & $\mathrm{H} \theta, \mathrm{H} 1$ \\
\hline MATENGENE & 0.33043419 & $1.852553078 \approx 1.852$ & 2.052 & 29 & N.S.T & & H0 V \\
\hline
\end{tabular}

The correlation test respectively shows varied values from 0.147937685 to 0.33043419 for KALEMBA Institute to MATENGENEZO Institute, in the correlation coefficient column. The conformity coefficients offer values corresponding to $\mathbf{O V}$ with critical values respectively from 2.064 at KALEMBA, 1.998 at KAVAGHENDI; 1.984 at Butembo; 2.037 at MALIO and 2.052 at MATENGENEZO.

The critical values of 2.064 at KALEMBA and 2.052 at MATENGENEZO are higher than the observed values. Therefore, the null hypothesis of non-existence of significant connections between school success of primary school sixth-year students and those of secondary school first year within these two secular schools is accepted. It is nonetheless rejected in favor of the affirmative at KAVAGHENDI, BUTEMBO, and MALIO. In terms of common variance, it is respectively $17.21 \%$ at KAVAGHENDI; 9.01 at BUTEMBO, and $22.85 \%$ at MALIO. 
Performance Correlational Possibility at the Transition between Two Levels: An Education Experience in a Congolese Urban Subdivision

Table6. Results Correlation of Students in Primary and Secondary Schools

\begin{tabular}{|c|c|c|c|c|c|c|c|}
\hline $\begin{array}{l}\text { Parameters } \\
\text { Institutes }\end{array}$ & $\begin{array}{c}\text { Correlation } \\
\text { coefficient }\end{array}$ & $\mathbf{O V}$ & $\mathrm{CV}$ & $n$ & $\mathbf{S c}$ & $\begin{array}{c}\text { Determination } \\
\text { coefficient }\end{array}$ & $\begin{array}{c}\text { Statistical } \\
\text { decision }\end{array}$ \\
\hline \multicolumn{8}{|c|}{ Catholic } \\
\hline LYAMBO & 0.672358936 & $7.545044664 \approx 7.545$ & 1.996 & 71 & S.T. & $45.20665388 \approx 45.20 \%$ & $\mathrm{HO}, \mathrm{H} 1 \mathrm{~L}$ \\
\hline MASIKILIZANO & 0.408747882 & $2.796950794 \approx 2.796$ & 2.023 & 41 & S.T & $16.7074831 \approx 16.70 \%$ & $\mathrm{HO}, \mathrm{H} 1 V$ \\
\hline LINGOMBE & 0.316050181 & $2.402201153 \approx 2.402$ & 2.008 & 54 & S.T. & 9.988771 & $\mathrm{HO}, \mathrm{H} 1 \mathrm{~V}$ \\
\hline Mont CARMEL & 0.476591634 & $6.228491103 \approx 6.228$ & 1.960 & 134 & S.T. & 22.713 & $\mathrm{HO}, \mathrm{H} 1_{\text {, }}$ \\
\hline Mgr KATALIKO & 0.58361815 & $6.013214265 \approx 6.013$ & 1.996 & 72 & S.T. & 34.061 & $\mathrm{HO}, \mathrm{H1}$ \\
\hline B JIOVANIE & 0.5158 & $4.039121592 \approx 4.039$ & 2.015 & 47 & S.T & 26.607 & $\mathrm{HO}, \mathrm{H} 1 \mathrm{~V}$ \\
\hline \multicolumn{8}{|c|}{ Seventh Day Adventists } \\
\hline PARAP & 0.126992506 & 0.778770434 & 2.027 & 39 & N.S.T, & & $\mathrm{HOV}$ \\
\hline MUTIRI & 0.434991456 & $3.773057978 \approx 3.773$ & 1.999 & 63 & S.T & 18.9217 & $\mathrm{HO}, \mathrm{H} 1$ \\
\hline \multicolumn{8}{|c|}{ CBCA Schools } \\
\hline KINYAVUYIRI & 0.484542509 & $6.459644107 \approx 6.459$ & 1.960 & 138 & S.T. & $23.4781443 \approx 23.47 \%$ & $\mathrm{H} \theta, \mathrm{H} 1 V$ \\
\hline LINZO & 0.63864749 & $5.048400048 \approx 5.048$ & 2.027 & 39 & S.T. & $40.78706165 \approx 40.78 \%$ & $\mathrm{HO}, \mathrm{H} 1 \mathrm{~V}$ \\
\hline \multicolumn{8}{|c|}{ CEBCE Schools } \\
\hline JOU-FURU & 0.675415697 & $5.49537524 \approx 5.495$ & 2.029 & 38 & S.T. & $45.61863638 \approx 45.61 \%$ & $\mathrm{HO}, \mathrm{H} 1 \mathrm{~L}$ \\
\hline VUVATSI & 0.383431406 & $2.935642519 \approx 2.935$ & 2.010 & 52 & S.T. & $14.70196431 \approx 14.70 \%$ & $\mathrm{HO}, \mathrm{H} 1 \mathrm{~V}$ \\
\hline KASOKERO & 0.213172192 & $1.414015345 \approx 1.414$ & 2.018 & 44 & N.S.T & & $\mathrm{H} 0 V$ \\
\hline
\end{tabular}

With the application of the Bravais Pearson test, the correlation coefficient column shows the values of LYAMBO: 0.672358936 at KASOKERO of which 0.213172192 of the CEBCE. The calculation of the conformity coefficient gives respective values from 7.545 to 3.098 KASOKERO such as shown in the OV column. Lastly, the respective critical values go from 1.996 at LYAMBO Institute up to 1.414 for KASOKERO Institute as shown in the $\mathbf{C V}$ column.

Elsewhere, the critical values of Catholic schools were lower than the calculated values. This confirms the existence of a significant positive similarity, even in the CBCA schools. However, among Adventist schools, MUTIRI proved the similarity but PARAPANDA did not. Further, 2/3 of CEBCE schools proved the significant positive similarity, among which JOU FURU and VUVATSI, respectively at 5.495 and 2.935 against KASOKERO (1.414) which did not yield any significant positive similarity of results for primary school students in 2015 on the success by the same students in the first secondary year.

Table7. Success Correlation in Primary $6^{\text {th }}$ Year and Secondary $1^{\text {st }}$ Year

\begin{tabular}{|c|c|c|c|c|c|c|c|}
\hline $\begin{array}{c}\text { Parameters } \\
\text { Schools }\end{array}$ & $\begin{array}{l}\text { Correlation } \\
\text { coefficient }\end{array}$ & $\mathbf{O V}$ & $\mathrm{CV}$ & $n$ & $\begin{array}{l}\text { Stat. } \\
\text { Concl. }\end{array}$ & D.C & Stat. dec. \\
\hline L'UNION & 0.426576447 & $2.261910946 \approx 2.261$ & 2.069 & 25 & S.T & $18.19674651 \approx 18.19 \%$ & $\mathrm{HO}, \mathrm{H} 1$ \\
\hline MWALIMUSEKI & I 0.767410636 & $5.614039924 \approx 5.614$ & 2.074 & 24 & S.T & $58.89190842 \approx 58.89 \%$ & $\mathrm{HO}, \mathrm{H} 1$ \\
\hline VATUNDI & 0.379464952 & $1.96696705 \approx 1.966$ & 2.069 & 25 & N.S.T & & HO V \\
\hline ABRAR YUSUF & 0.337093997 & $1.860484068 \approx 1.860$ & 2.052 & 29 & N.S.T & & $\mathrm{HO} V$ \\
\hline SC ESPERANCE & 0.254471733 & $1.146974733 \approx 1.146$ & 2.093 & 21 & N.S.T & & H0 V \\
\hline CS LE ROCHER & 0.666673503 & $3.098443868 \approx 3.098$ & 2.179 & 14 & S.T & $44.44535596 \approx 44.44 \%$ & $\mathrm{HO}, \mathrm{H} 1$ \\
\hline EMEDY & 0.253351425 & $1.795468253 \approx 1.795$ & 2.013 & 49 & N.S.T & & $\mathrm{H} 0 \vee$ \\
\hline SC VICTORINE & 0.301466296 & $2.469411901 \approx 2.469$ & 1.999 & 63 & S.T & $9.088192762 \approx 9.08 \%$ & $\mathrm{HO}, \mathrm{H} 1$ \\
\hline SAUVETAGE & 0.225425573 & $1.636112405 \approx 1.636$ & 2.010 & 52 & N.S.T & & Ho V \\
\hline SC MENUIBO & 0.534225751 & $3.996892272 \approx 3,996$ & 2.021 & 42 & S.T & $28.5397153 \approx 28.53 \%$ & $\mathrm{HO}, \mathrm{H} 1$ \\
\hline CEPROMAD & 0.542833342 & $4.036472855 \approx 4.036$ & 2.022 & 41 & S.T & $29.46680372 \approx 29.46 \%$ & $\mathrm{HO}, \mathrm{H} 1$ \\
\hline REFERENCE & 0.706683707 & $5.909006744 \approx 5.909$ & 2.031 & 37 & S.T. & $49.94018617 \approx 49.94 \%$ & $\mathrm{HO}, \mathrm{H} 1$ \\
\hline KIRUNDI & 0.331308689 & $2.979523746 \approx 2.979$ & 1.996 & 74 & S.T. & $10.97654474 \approx 10.97 \%$ & $\mathrm{HO}, \mathrm{H} 1$ \\
\hline GPSCOLAIRE & 0.521064312 & $4.35977452 \approx 4.359$ & 2.009 & 53 & S.T & $27.15080172 \approx 27.15 \%$ & $\mathrm{HO}, \mathrm{H} 1$ \\
\hline SC APOTRE I & 0.305545005 & $2.85213946 \approx 2.852$ & 1.993 & 81 & S.T & $9.335775008 \approx 9.33 \%$ & $\mathrm{H} 0, \mathrm{H} 1$ \\
\hline SC MIGNONNE & 0.468313108 & $3.13568928 \approx 3.135$ & 2.031 & 37 & S.T & $21.93171671 \approx 21.93 \%$ & $\mathrm{HO}, \mathrm{H} 1$ \\
\hline
\end{tabular}

The Bravais Pearson test gives the values of the correlation coefficient column, going from 0.426576447 at Union Institute to 0.468313108 for the Complexe Scolaire La Mignonne. The 
conformity coefficient shows values of 2.261 for the Union Institute up to 3.135 for the Complexe Scolaire La Mignonne. Thus, from the threshold of $95 \%$, we get the respective critical values of 2.069 at the Union up to 2.031 of La Mignonne, as shown in the conformity rate column (cr).

The critical values at Vatundi Institute (2.069); at Abrar YUSUFU (2.052), at l'Espérance (2.093), at Emedy (2.013) and at Sauvetage (2.010) being higher than the observed lead to accept the null hypothesis rejecting the existence of significant similarity between the school result attained in 2015 Primary sixth year and in 2016 Secondary first year in Butembo City. Nonetheless, the observed values (2.261) of l'Union Institute up to 3.135 of the Complexe Scolaire La Mignonne revealed higher than the theoretical values, lead to reject the null hypothesis in favor of the alternative of the existence of a low association of significant positive similarity for the above-mentioned schools in the same column.

Taking into account the shared variance, it emerges respectively a value of $18.19 \%$ at l'Union ; $58.89 \%$ at Mwalimu Seki; $44.44 \%$ at the Complexe Scolaire Le Rocher; 9.08\% at the Complexe Scolaire La Sainte Victorine; $28.53 \%$ at the Complexe Scolaire Menuibo; 29.46\% at 1'Edac Cepromad; $49.94 \%$ at the Complexe Scolaire La Référence; $10.97 \%$ at Katwa Kirundi; $27.15 \%$ at the Groupe Scolaire; 9.33\% at the Complexe Scolaire Apôtre I, and 21.93 at the Complexe Scolaire La Mignonne, as being the influence of the school performance of Secondary school first year by the Primary school sixth year in private schools.

\subsection{Interpretive Analysis of Performance Correlation}

We are dealing with the performance correlation possibility between the two school levels. The end of primary studies and the beginning of the secondary cycle in Butembo City during the years 2015 and 2016 was the basis for this research study. By checking whether a positive significant correlation was possible and effective between the school successes of students at the two levels, we wanted to encourage the education system to improve education and society or to redirect it in case of doubtful attribution of school success.

Applied to our data, the Bravais Pearson correlation test showed that the student school success in the 2015 Primary sixth year truly influenced their success in the Secondary first year. The significant positive correlation has therefore been possible but differently lived in different schools. It was about a shared variance of $15.72 \%$ only against $84.28 \%$ explainable by motivation, the type of teaching, the student ability, the socio-economic environment, the political aspect.

However, and still by the same Bravais Pearson correlation test, we discovered the following. First, from the gender variable, there has been a low positive significant similarity for girls: a determination coefficient of $14.69 \%$ only, against $85.31 \%$. For boys, the connection was rather more stressed at $16.79 \%$ against $83.21 \%$ as shown. It is therefore clear that the best connection varies according to gender.

Second, from the management network, a low significant positive connection was proven with a determination coefficient of only $10.08 \%$ against $89.92 \%$ in secular schools. On the contrary, in religious schools such the Catholic ones, students' results presented a significant positive connection more stressed with a common variance of $25.09 \%$ against $74.91 \%$. In Adventist schools, it is by halves, with a determination coefficient of 5.35\%. In CBCA schools, it was also more stressed with a shared variance of $25.89 \%$ against $74.11 \%$. On the contrary, in CEBCE schools, this positive connection presented by Primary sixth year students then in Secondary first year is $11.44 \%$ against $88.56 \%$. It is in the Kimbanguist Religious Schools that the best significant positive correlation was observed, with a determination coefficient of $40.55 \%$ against $59.45 \%$ for the rest, explaining by other factors the overwhelming success in primary school, then in the first year of the secondary school. They are, respectively followed by the Anglican schools, with a common variance of $40.13 \%$ against $59.87 \%$. The last analysis shows CECA 20 schools with a shared variance of $33.08 \%$ against $66.92 \%$; Islamic schools, with a common variance of $30.16 \%$ against $69.84 \%$; and later CEBA schools, with a determination of $15.89 \%$ against $84.11 \%$. In private schools, a low significant positive connection is equally observed. Its shared variance is $12.78 \%$ of success influence against $87.22 \%$.

From this presentation, the variation of the success influence for students in the secondary first year by that of the primary in the management network is well proved. The hypothesis consecrating this 
correlation is qualified: this influence is not similar by gender or by network management. A low significant positive correlation was observed at the BUTEMBO Institute and more stressed at the KAVAGHENDI and MALIO institutes with shared variances respectively of $9.01 \%$ at BUTEMBO Institute, $17.21 \%$ at KAVAGHENDI, and $22.85 \%$ at MALIO.

In religious schools, such as at the Catholic ones, the low significant positive association was found at the LINGOMBE Institute, but more stressed at MONT CARMEL, Mgr KATALIKO, MASIKILIZANO, the CS BEGUE VIOVANNE, and LYAMBO. The respective determination coefficients were $45.20 \%$ at LYAMBO, $16.70 \%$ at MASIKILIZANO, 9.98\% at LINGOMBE; $22.71 \%$ at MONT CARMEL, $34.06 \%$ at MGR KATALIKO, and $26.60 \%$ at CS VIOVANNE.

In Adventist Schools, no significant correlation was revealed at PARAPANDA Institute but it was present at MUTIRI Institute with a determination coefficient of $18.92 \%$. The CBCA schools showed it, more stressed at the KINYABYIRI Institute, good at the LINZO Institute with respective determination coefficients of $23.47 \%$ and $40.78 \%$. For the CEBCE network, no significant association was observed at KASOKERO Institute, whereas it is revealed at VUVATSI and good at JOU-FURU, with respective shared variances of $14.70 \%$ and $45.61 \%$. In the CEBA religious schools, no significant correlation was noticed at MUTSOPERWA Institute, whereas it was positively evident but proved low at NDEREMBI with a $13.42 \%$ variance.

In private schools, there was no significant correlation between the school results of the Primary sixth year and those of the Secondary first year in the VATUNDI, Abrar YUSUFU, l'ESPERANCE, EMEDY, and SAUVETAGE institutes. There was a low correlation at the COMPLEXE SCOLAIRE SAINTE VICTORINE, APOTRE I and at the KATWA KIRUNDI institutes, which was positively more stressed at l'UNION, MENUIBO, EDAC CEPROMAD, and MIGNONNE, and a good one at MWALIMU SEKI, LE ROCHER, and at LA REFERENCE institutes with respective shared variances such as indicated in the determination coefficients.

In terms of analysis, the performance correlation possibility when passing from one study level to another was effective, although at divergent degrees. It was similar neither by gender nor by network management, even less by school in the same network. The excellent achievement at the end of the primary greatly influenced and still influences the success in the first year of the secondary schools. It is a success tonicity of important emulation created in the learner. Its role is most important, but it is the only one; other numerous factors having contributed to the difference in proportion.

\section{CONCLUSION AND RECOMMENDATIONS}

It is always necessary to ask scientific questions about a mass success. Our study about performance correlation possibility when moving from one level to another is within this framework. It is this overwhelming success of the 2014-2015 PENT in Butembo which generated the curiosity of questions about the credibility of this success, whether this mind-blowing success would be reflected at the beginning of the next level. From the results, we need to check this influence taking into account the gender and network management factors.

We initially assumed that the best results at the end of a cycle should reflect on the beginning of the next cycle, but at a lesser degree and with diverse proportions. As a pattern, the factors which are to be taken into account in a school success are numerous. Without being exhaustive, these may include the physical, physiological, and sanitary factors; psychological factors among which motivation, ability and interest of the learners; physical and social environmental factors among which distance, the teachers and the teaching strategies, the family and its social, economic, even political aspects.

Analytically supported by documentary techniques and statistics, the correlation method led us to the conclusion that school performance of a learner at a certain level significantly influences another. But, it is not possible for the correlation to be identical or even of the same degree given the differences between individuals, their motivation, the school, and the economic and social conditions of the learners.

In order to keep this correlation efficiency high, governments should keep harmonious the teaching programs between cycles, train the teachers end strengthen the continuous training system. Similarly, the teachers have a right to a motivating and adequate remuneration. In addition, the school-family partnership should be strengthened for the good education of the children. Better still, the inspectorate should be encouraged to insure a follow-up and a regulation of the school system at all levels. 


\section{REFERENCES}

[1] David HOWELL C, (1998) Méthodes statistiques en sciences humaines, Deboeck, Paris.

[2] De LANDSHEERE (1980), L'évaluation continue et examen précis de docimologie, Bruxelles,

[3] DEKETELE, J.M (1986), Docimologie, introduction aux concepts et aux pratiques, Cabay, Louvain.

[4] DRÉANO Guy (2015), Guide de l'éducation spécialisée, $5^{\mathrm{ème}}$ éd. Dunod, Paris.

[5] DURU BELLAT M. et MINGAT A. (1997), La gestion de l'hétérogénéité des publics d'élèves au collège, PUF, Paris.

[6] Guimard P, Cosnefroy O et Florin A, (2007) Évaluation des comportements et des compétences scolaires par les enseignants et prédiction des performances et des parcours à l'école élémentaire et au collège, INETOP, Paris.

[7] KAKULE MUKULU, E. (2015-2016) Analyse et prédiction factorielle, unpublished course, FPSE, UOR.

[8] KAVIRA SYALIKOWIWE Bilha (2014-2015) Statistique inductive II, unpublished course, FPSE, UOR.

[9] LAENG.M Vocabulaire de pédagogie moderne, éd. France empire, Paris, 1971

[10] LAFON.R (1991) Vocabulaire de la psychologie et de psychiatrie de l'enfant, PUF, Paris.

[11] LAFON.R (1991), Vocabulaire de la psychologie et de psychiatrie de l'enfant, PUF, Paris.

[12] LETHAN KHOI (1967), L'industrie de l'enseignement, éd. PUF, Paris.

[13] LETHANKHOI, (1967) L'industrie de l'enseignement, éd. PUF, Paris.

[14] MARTIN. J. ET NADEAU R. «évaluation des programmes », éd. Québec, 1998

[15] MINEDUC, (2010) Guide pratique de gestion de TENAFEP, Kinshasa

[16] PIERON. H, Examens et docimologie, Paris, PUF 1996

[17] PLANCHERD, E. (1998), La pédagogie scolaire contemporaine, Casterman, Paris.

[18] YADOLAH, D. (1993), Dictionnaire encyclopédique de la statistique, DUNOD, Paris.

\section{AUTHOR'S BIOGRAPHY}

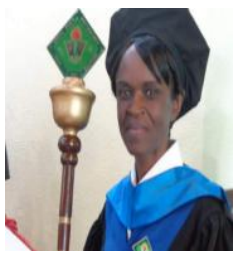

Dr. Kahambu Matita completed her master's degree at the University of Kisangani, Democratic Republic of Congo, in 1990. She then pursued an educational specialist degree at the same university, which she completed in 200. She then went to the Philippines and obtained her PhD in Education from Cavite State University in 2013. She is currently a professor and dean of the Department of Psychology and Education at the State University of Ruwenzori (l'Universite Officielle de Ruwenzori) in Butembo, Democratic Republic of Congo. She is passionate about educational administration and instructional supervision in higher education. She is married and has 6 children.

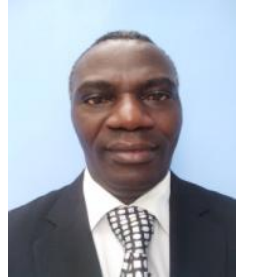

Prof. Leandre Thamuithe completed a master's degree at the University of Kisangani, in the Democratic Republic of Congo, in 1999. He then completed an educational specialist degree in the same field in 2003 at the same university. In 2017, he completed a master's degree in criminology at the University of the Cordilleras, in the Philippines. He is currently completing a PhD program in criminology at the same university in the Philippines. His research interest is in conflict management and crime prevention in modern society.

Citation: Kahambu Matita, PhD, Leandre Thamuithe, PhD Student. “ Performance Correlational Possibility at the Transition between Two Levels: An Education Experience in a Congolese Urban Subdivision". International Journal of Humanities Social Sciences and Education (IJHSSE), vol 5, no. 3, 2018, pp. 96-104 doi: http://dx.doi.org/10.20431/2349-0381.0503010.

Copyright: (c) 2018 Authors. This is an open-access article distributed under the terms of the Creative Commons Attribution License, which permits unrestricted use, distribution, and reproduction in any medium, provided the original author and source are credited. 